Prepared for the U.S. Department of Energy

under Contract DE-AC05-76RL01830

\title{
Effects of Electromagnetic Fields on Fish and Invertebrates
}

\section{Task 2.1.3: Effects on Aquatic Organisms - Fiscal Year 2010 Progress Report}

Environmental Effects of Marine and Hydrokinetic Energy
IR Schultz
WJ Pratt
DL Woodruff
G Roesijadi
KE Marshall

October 2010

\section{Pacific Northwest}

NATIONAL LABORATORY

Proudly Operated by Battelle Since 1965 


\title{
DISCLAIMER
}

This report was prepared as an account of work sponsored by an agency of the United States Government. Neither the United States Covernment nor any agency thereof, nor Battelle Memorial Institute, nor any of their employees, makes any warranty, express or implied, or assumes any legal liability or responsibility for the aceuracy, completeness, or usefulness of any information, apparatus, product, or process disclosed, or represents that its use would not infringe privately owned rights. Reference herein to any specific commereial product, process, or service by trade name, trademark, manufacturer, or otherwise does not necessarily constitute or imply its endorsement, recommendation, or favoring by the United States Government or any agency thereof, or Battelle Memorial Institute. The views and opinions of authors expressed herein do not necessarily state or reflect those of the United States Government or any agency thereof.

\author{
PACIFIC NORTIIWEST NATIONAL LABORATORY \\ operated by \\ BA'T'IELLE \\ for the \\ UNITED STATES DFPARTMENT OF ENFRGY \\ under Contract DE-AC05-76RL01830 \\ Printed in the United States of America
Available to DOE and DOF contractors from the Office of Scientific and Technical Information,
P.O. Box 62, Oak Ridge, TN 37831-0062;
ph: (865) 576-8401
fax: (865) 576-5728
email: reports $(a$ adonis.osti.gov

\begin{abstract}
Available to the public from the National Technical Information Service,
U.S. Department of Commeree, 5285 Port Royal Rd., Springfield, VA 22161

ph: (800) 553-6847

fax: $(703) 605-6900$

email: orders antis.fedworld.gov
\end{abstract} \\ online ordering: http://www.ntis.gov/ordering.htm
}

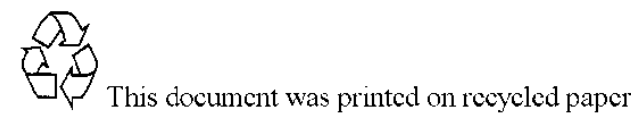




\section{Effects of Electromagnetic Fields on Fish and Invertebrates}

Task 2.1.3: Effects on Aquatic Organisms Fiscal Year 2010 Progress Report

Environmental Effects of Marine and Hydrokinetic Energy

IR Schultz

DL Woodruff

KE Marshall
WJ Pratt

G Roesijadi

October 2010

Prepared for

the U.S. Department of Energy

under Contract DE-AC05-76RL01830

Pacific Northwest National Laboratory

Richland, Washington 99352 



\begin{abstract}
In this progress report, we describe the preliminary experiments conducted with three fish and one invertebrate species to determine the effects of exposure to electromagnetic fields. During fiscal year 2010, experiments were conducted with coho salmon (Onchorhychus kisutch), California halibut (Paralicthys californicus), Atlantic halibut (Hippoglossus hippoglossus), and Dungeness crab (Cancer magister). The work described supports Task 2.1.3: Effects on Aquatic Organisms, Subtask 2.1.3.1: Electromagnetic Fields.
\end{abstract}





\section{Project Overview}

Energy generated from the world's oceans and rivers offers the potential to make substantial contributions to the domestic and global renewable energy supply. The U.S. Department of Energy (DOE) Office of Energy Efficiency and Renewable Energy (EERE) Wind and Water Power Program supports the emerging marine and hydrokinetic (MHK) energy industry. As an emerging industry, MHK project developers face challenges with siting, permitting, construction, and operation of pilot- and commercial-scale facilities, as well as the need to develop robust technologies, secure financing, and gain public acceptance.

In many cases, little is known about the potential effects of MHK energy generation on the aquatic environment from a small number of devices or a large-scale commercial array. Nor do we understand potential effects that may occur after years or decades of operation. This lack of knowledge affects the solvency of the industry, the actions of regulatory agencies, the opinions and concerns of stakeholder groups, and the commitment of energy project developers and investors.

To unravel and address the complexity of environmental issues associated with MHK energy, Pacific Northwest National Laboratory (PNNL) is developing a program of research and development that draws on the knowledge of the industry, regulators, and stakeholders and builds on investments made by the EERE Wind and Water Power Program. The PNNL program of research and development- together with complementary efforts of other national laboratories, national marine renewable energy centers, universities, and industry - supports DOE's market acceleration activities through focused research and development on environmental effects and siting issues.

Research areas addressed include

- Categorizing and evaluating effects of stressors - Information on the environmental risks from MHK devices, including data obtained from in situ testing and laboratory experiments (see other tasks below) will be compiled in a knowledge management system known as Tethys to facilitate the creation, annotation, and exchange of information on environmental effects of MHK technologies. Tethys will support the Environmental Risk Evaluation System (ERES) that can be used by developers, regulators, and other stakeholders to assess relative risks associated with MHK technologies, site characteristics, waterbody characteristics, and receptors (i.e., habitat, marine mammals, and fish). Development of Tethys and the ERES will require focused input from various stakeholders to ensure accuracy and alignment with other needs.

- Effects on physical systems - Computational numerical modeling will be used to understand the effects of energy removal on water bodies from the short- and long-term operation of MHK devices and arrays. Initially, PNNL's three-dimensional coastal circulation and transport model of Puget Sound will be adapted to test and optimize simulated tidal technologies that resemble those currently in proposal, laboratory trial, or pilot study test stages. This task includes assessing changes to the physical environment (currents, waves, sediments, and water quality) and the potential effects of these changes on the aquatic food webs) resulting from operation of MHK devices at both pilot- and commercial-scale in river and ocean settings.

- Effects on aquatic organisms - Testing protocols and laboratory exposure experiments will be developed and implemented to evaluate the potential for adverse effects from operation of MHK devices in the aquatic environment. Initial studies will focus on electromagnetic field effects, noise 
associated with construction and operation of MHK devices, and assessment of the potential risk of physical interaction of aquatic organisms with devices. A variety of fish species and invertebrates will be used as test animals, chosen due to their proximity to and potential susceptibility to MHK devices.

- Permitting and planning - Structured stakeholder communication and outreach activities will provide critical information to the project team to support execution of other project tasks. Input from MHK technology and project developers, regulators and natural resource management agencies, environmental groups, and other stakeholder groups will be used to develop the user interface of Tethys, populate the database, define the risk attributes of the ERES, and communicate results of numerical modeling and laboratory studies of exposure of test animals to MHK stressors. This task will also include activities to promote consideration of renewable ocean energy in national and local Coastal and Marine Spatial Planning activities.

The team for Activity 2.0 - MHK Environmental Impacts \& Siting - is made up of staff, faculty, and students from

- Pacific Northwest National Laboratory

- Marine Sciences Laboratory (Sequim and Seattle, Washington)

- Risk and Decision Sciences (Richland, Washington)

- Knowledge Systems (Richland, Washington)

- Oak Ridge National Laboratory (Oak Ridge, Tennessee)

- Sandia National Laboratories (Albuquerque, New Mexico; Carlsbad, California)

- Oregon State University, Northwest National Marine Renewable Energy Center (Newport, Oregon)

- University of Washington, Northwest National Marine Renewable Energy Center (Seattle, Washington)

- Pacific Energy Ventures (Portland, Oregon). 


\section{Acronyms and Abbreviations}

$\begin{array}{ll}\mathrm{cm} & \text { centimeter(s) } \\ \text { DOE } & \text { U.S. Department of Energy } \\ \text { EERE } & \text { DOE Office of Energy Efficiency and Renewable Energy } \\ \text { EMF } & \text { electromagnetic fields } \\ \text { ERES } & \text { Environmental Risk Evaluation System } \\ \mathrm{ft} & \text { foot, feet } \\ \mathrm{gal} & \text { gallon(s) } \\ \mathrm{hr} & \text { hour(s) } \\ \mathrm{in} . & \text { inch(es) } \\ \mu \mathrm{m} & \text { micrometer } \\ \text { MHK } & \text { marine and hydrokinetic } \\ \mathrm{mL} & \text { milliliter(s) } \\ \text { mT } & \text { millitesla } \\ \text { NOAA } & \text { National Oceanic and Atmospheric Administration } \\ \text { PNNL } & \text { Pacific Northwest National Laboratory }\end{array}$





\section{Contents}

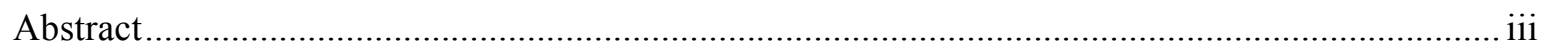

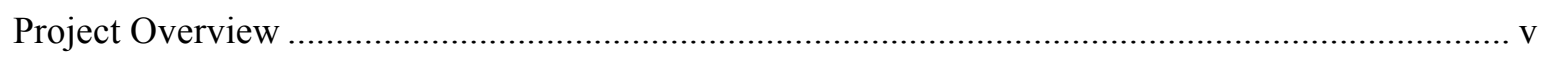

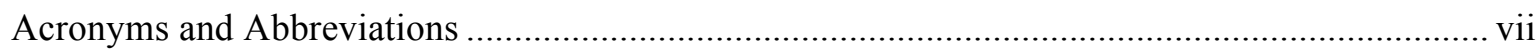

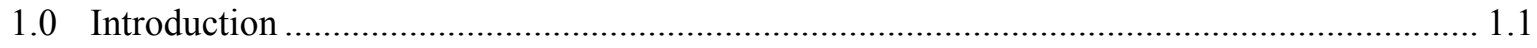

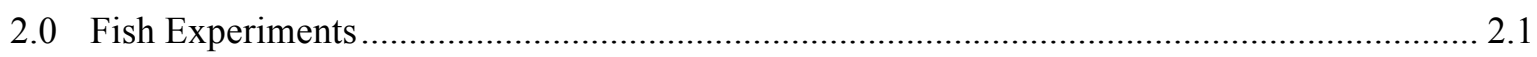

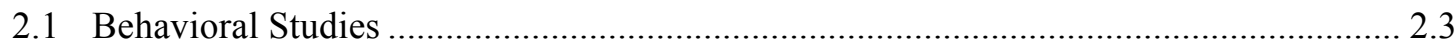

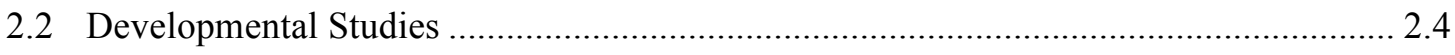

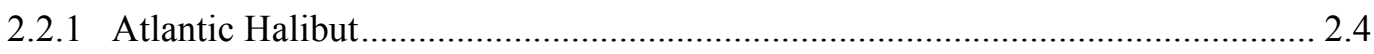

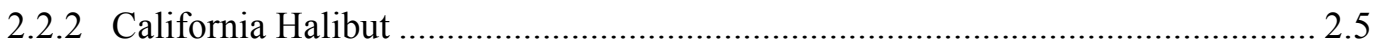

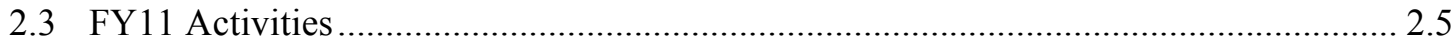

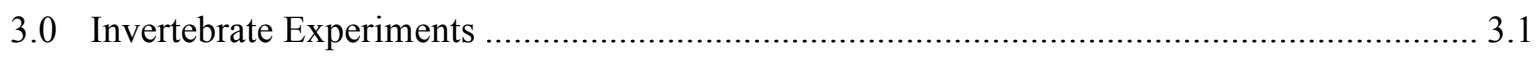

3.1 Dungeness Crab Behavioral Experiments ............................................................... 3.1

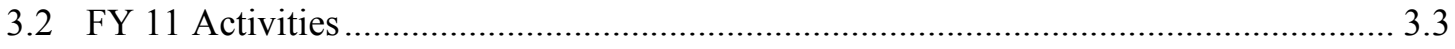

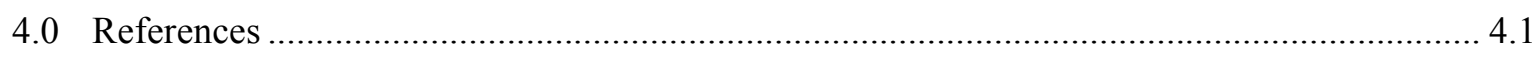

\section{Figures}

2.1 Field Strength Generated by the Helmholtz Coils ................................................................ 2.2

2.2 Experimental System for Coho Salmon and Atlantic Halibut.................................................. 2.2

2.3 Experimental System for California Halibut ...................................................................... 2.3

3.1 Antennules of Dungeness Crab Used in the EMF Exposure Tests ......................................... 3.1

3.2 Exposure System for Dungeness Crab ........................................................................... 3.2

3.3 Visual Partitions, Recording Cameras, and Monitoring System for Dungeness Crab Studies .... 3.3 



\subsection{Introduction}

As part of Task 2.1.3, Effects on Aquatic Organisms, Subtask 2.1.3.1 is focused on evaluating the potential effects of electromagnetic fields (EMF) exposure on fish and invertebrates. This report documents the preliminary experimental work conducted in FY 2010 to evaluate those effects.

The behavioral and developmental experiments with three species of fish are documented in Section 2. Section 2 also includes a description of the Helmholtz coil system, including system setup, calibration, and use, purchased by PNNL for the EMF exposure studies. Exposure experiments with a single invertebrate specie are described in Section 3. Section 4 provides a listing of the sources cited in this report. 



\subsection{Fish Experiments}

Fish experiments for FY10 focused on creating the EMF exposure system and developing protocols to assess whether behavioral effects and morphological changes would occur in selected fish species from exposure to EMF. Preliminary behavioral studies were conducted on coho salmon (Oncorhynchus kisutch); developmental effects studies were conducted on larval Atlantic halibut (Hippoglossus hippoglossus) and California halibut (Paralicthys californicus). To ensure uniform EMF could be produced in a space large enough for testing, PNNL purchased a large Hemholtz coil system capable of generating EMF ranging from approximately 0.1 to 3 millitessla (mT) under direct current operation and lower EMF using alternating current. An upper level of $3 \mathrm{mT}$ was chosen because it was consistent with exposure ranges used in previous studies conducted by other researchers on fish and invertebrates. The Helmholtz coil experimental system was purchased by PNNL using internal overhead funds, and was received at the PNNL Marine Sciences Laboratory on June 8, 2010. Approximately 1 month was spent installing and testing the system prior to use in exposure assessment.

Before the experiments were conducted, the EMF field generated by the Helmholtz coils was mapped to determine if PNNL's requested specifications were met and to quantify the EMF test organisms would experience between the coils. The coils framed an area that was $24 \mathrm{in}$. wide $\times 60 \mathrm{in}$. long $\times 40 \mathrm{in}$. high. A grid was established between the coils at 4-in. intervals vertically and horizontally, and EMF strength was determined using a Holaday HI-3550 magnetic field monitor. A three-dimensional (3-D) image depicting field strength (Figure 2.1) was generated using the MATLAB software 3D plotting function (The MathWorks Inc., Natick, Massachusetts). The highest field strength generated was along the $y$-axis at $4 \mathrm{in}$. and $20 \mathrm{in}$. where the coils are positioned; the average field strength was $3.2 \pm 0.13 \mathrm{mT}$, which is 64 times stronger than the Earth's magnetic field. The majority of the testing area is between 2.5 and 3.5 $\mathrm{mT}$, which provided a uniform-field-testing area within a cube 24 in. to a side and met our stated requirements for exposure effects testing.

Based on the field mapping, the test system was designed to confine fish within the strongest part of the field. Coho salmon and Atlantic halibut were contained in a $2-\mathrm{ft}^{3}$ acrylic cube situated in the middle of the field (Figure 2.2), while California halibut were contained in 2.5-gal aquaria nested in large water baths with aeration and static water renewal (Figure 2.3). A flow-through water system kept the water level at $1 \mathrm{ft}$ and provided fresh circulating water to the cube. A similar cube was placed more than $6 \mathrm{ft}$ outside of the coils to control for inherent setup effects. Both cubes were wrapped in black plastic to reduce the light intrusion and to minimize visual disturbances. Video cameras to record all experiments were placed in the vertical and horizontal planes to monitor fish behavior remotely. 


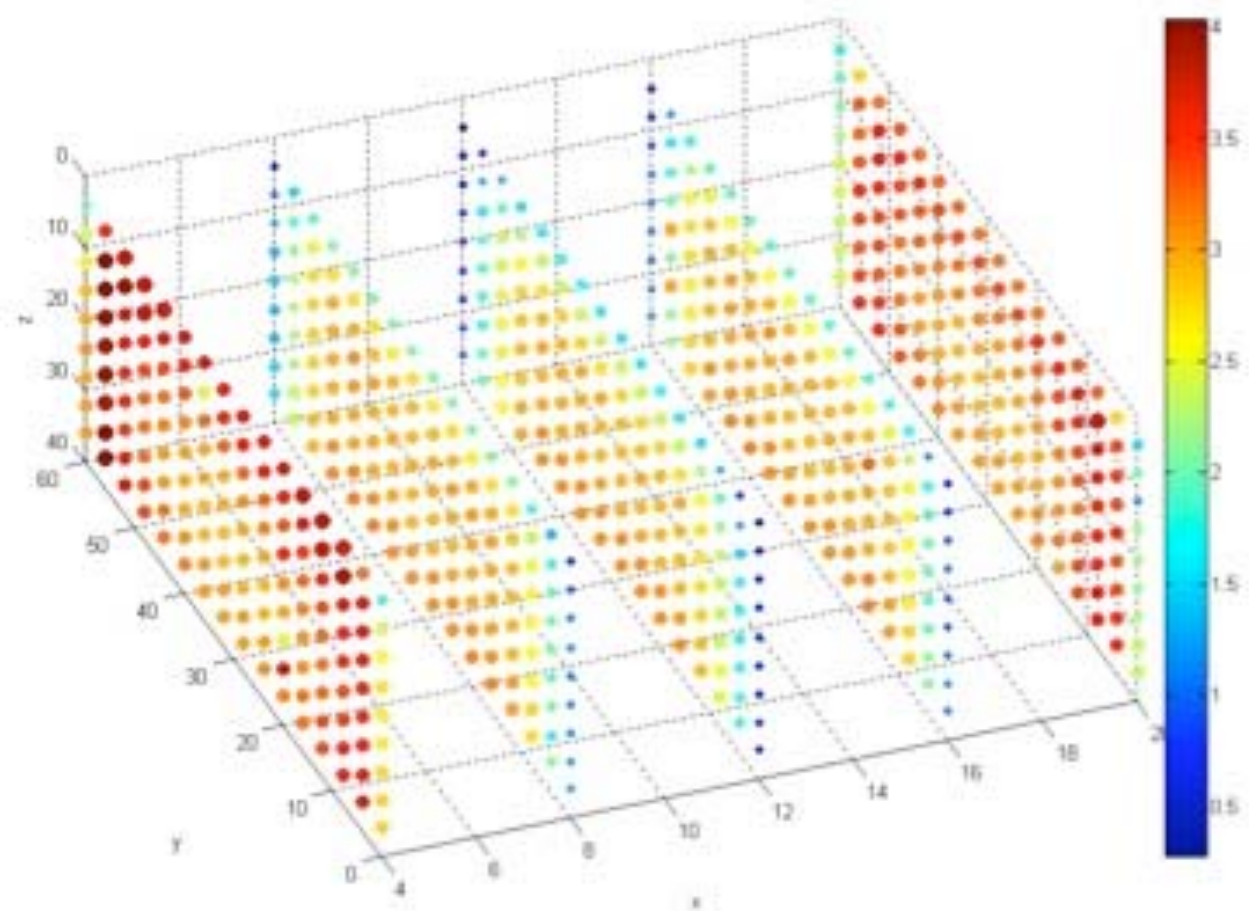

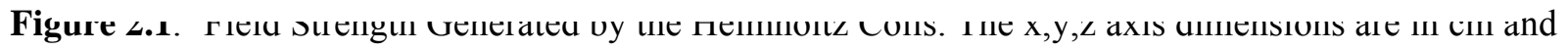
field strength (noted by color) is in $\mathrm{mT}$.

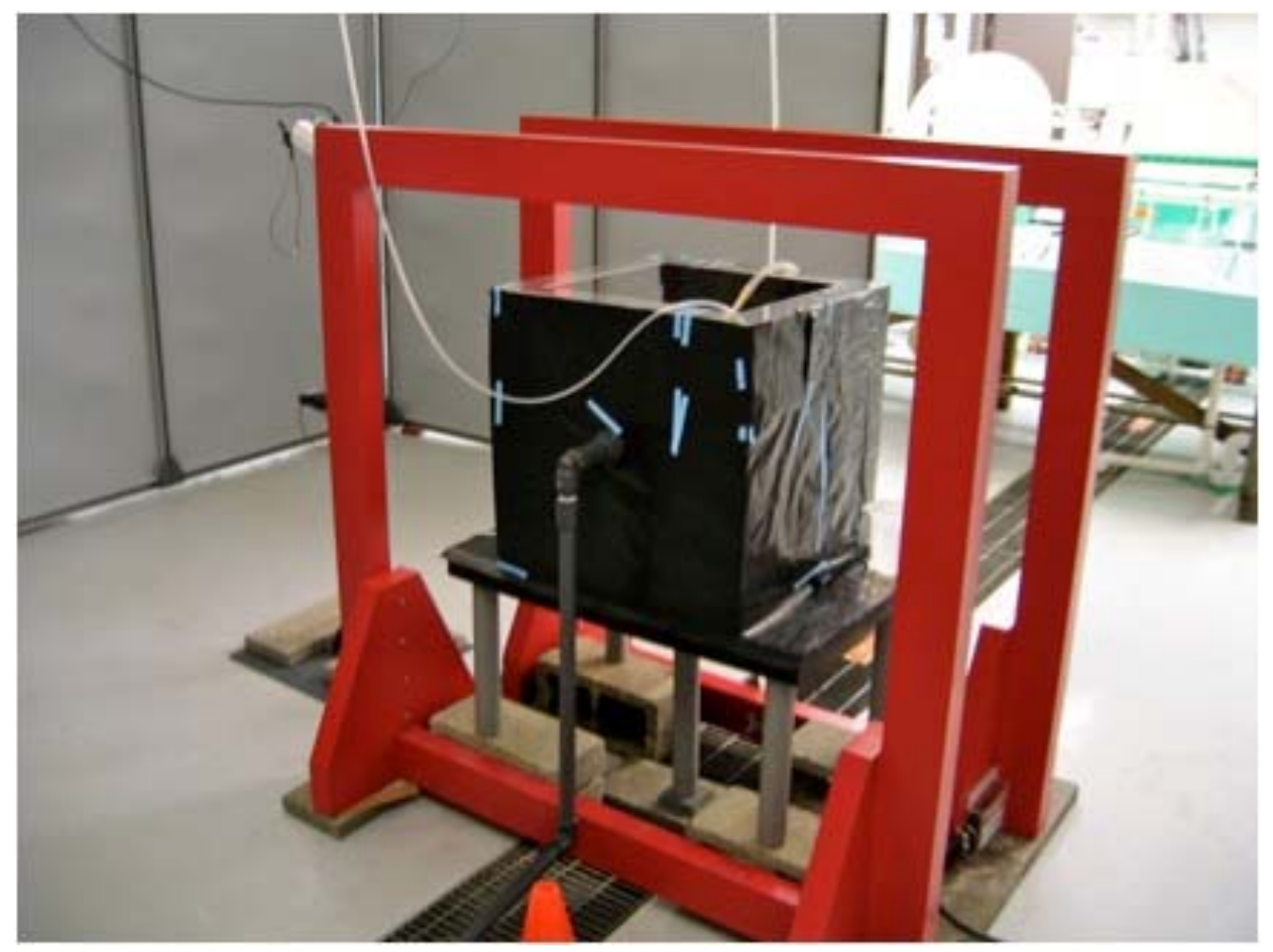

Figure 2.2. Experimental System for Coho Salmon and Atlantic Halibut 


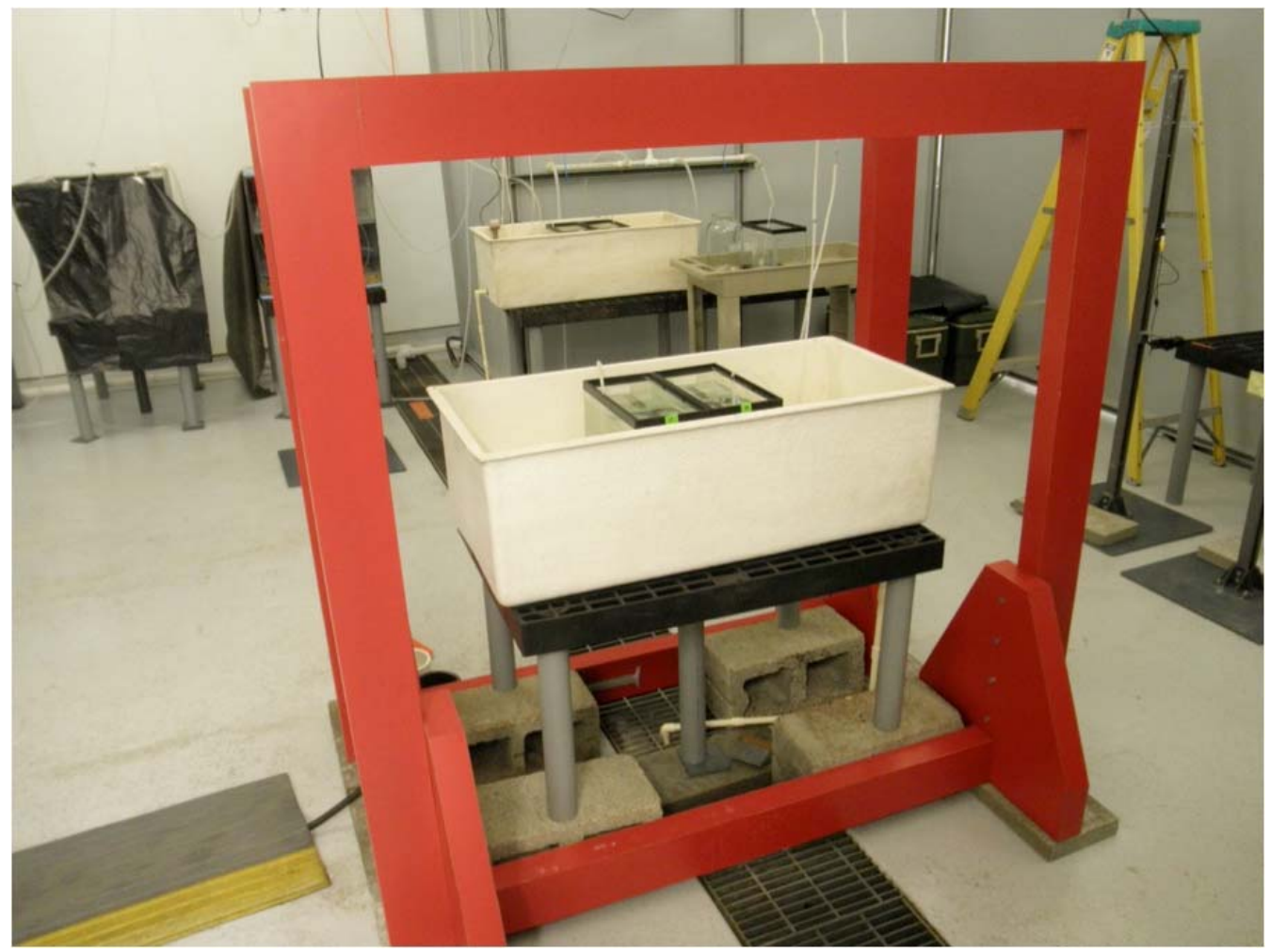

Figure 2.3. Experimental System for California Halibut

\subsection{Behavioral Studies}

For behavioral studies, juvenile coho salmon (approximately 6-in. fork length) were exposed to EMF and then stimulated with a predatory alarm substance to determine if their predator avoidance behavior had been affected by EMF exposure. This response has been used by the National Oceanic and Atmospheric Administration (NOAA) Fisheries and others (Stone et al. 1994; Brown and Smith 1997; Scholz et al. 2000; Tierney et al. 2006) to determine if exposure to chemicals from stormwater or other sources affects the predator-response ability of these fish. For EMF exposures, each experiment was conducted using 1 to 5 hatchery-reared juvenile salmon that had been acclimated in the exposure cubes for 7 days. Following acclimation, the fish were exposed to a static 3-mT field for 1-14 days. A predatory alarm substance consisting of $10 \mathrm{~mL}$ of homogenized coho salmon skin was added to the tank through a remote syringe apparatus to simulate a predator, and fish response was monitored by the video cameras.

Under non-stressed conditions, coho salmon were expected to swim throughout the water column. When the alarm substance was added, the fish were expected to become motionless until the alarm substance was diluted by clean water inflow and cleared from the cube (Brown and Smith 1997). Four experiments were conducted in which the salmon were exposed to EMF for varying lengths of time and then introduced to the predatory alarm substance. During the first two experiments, the alarm substance was introduced during the daytime hours when the lights were on. Throughout the exposure, the fish remained situated primarily at the bottom of the cube and moved very little within the water column prior to and after the alarm substance was introduced. This response indicated the fish were displaying the stereotypical avoidance behaviors constantly throughout the experiment. 
Through video monitoring of the non-EMF exposed control tank under non-stressed conditions, fish were observed to be more active at night when the lights were off. For this reason, the original protocol was altered to add the alarm substance $30 \mathrm{~min}$ after the lights went off instead of during the day. The experiments in the dark conditions provided variable results.

During the third trial, fish were exposed to EMF 5 days prior to the addition of the predator stimulus. The skin extract was added to the tanks $30 \mathrm{~min}$. after dark, and fish were monitored for the behavior. Before the extract was added, fish were observed swimming in the water column at various depths within the cube. Immediately after the extract was added, the fish displayed noticeable defensive behaviorschooling at the bottom of the cube, becoming increasingly motionless, and aligning themselves into the flow of water. This behavior lasted 30-60 min following stimulus addition; the fish returned to the full water column once the alarm substance was cleared from the cube. For this trial, the observed behavioral response suggested that exposure to EMF did not inhibit the alarm response in coho salmon.

During the fourth trial, fish were exposed to 1 day of EMF and the stimulus was added 30 min after dark. In the video footage, the fish appeared to be displaying an alarm response both prior to and after the addition of the skin extract. It is possible the variability in behavior between trials three and four could be due to human disturbances prior to the addition of the alarm substance. Because the fish respond to light cues, adding the alarm substance in the dark with low-level auxiliary lighting may have created shadows that were interpreted as predator movement by the test fish. Follow-on studies are planned to use an alternative lighting source and streamline the addition of the stimulus to minimize fish disturbance before repeating the behavioral studies.

\subsection{Developmental Studies}

To determine if EMF exposure affects the development of fish larvae, two different species of flatfish were chosen for experimentation. Atlantic halibut and California halibut have well-characterized developmental stages and therefore are good model organisms to use for these experiments (Gisbert et al. 2002; Saele et al. 2003).

\subsubsection{Atlantic Halibut}

Atlantic halibut were received from Scotian Halibut, Inc. (Nova Scotia, Canada) at approximately 26 days post-first feed. Fish were placed in holding tanks for 3 days and then transferred into experimental cubes for testing.

Atlantic halibut were subjected to EMF under two experimental trials. The first trial was designed to run for 14 days; however, unexpected water temperature increases affected fish survival, and the experiment was terminated after only 5 days. The second trial addressed the water temperature issue with the addition of a water chilling system to the inflow to maintain a steady temperature well within the range of Atlantic halibut survivability.

With the temperature stabilized, the second experiment consisted of one tank per treatment group with 10 fish per tank for the EMF exposure and the non-EMF exposure control. The experiment was started when the fish were considered to be within 7-10 days of completing the transformation from larvae to juveniles (metamorphosis). The data collected from this initial experiment suggested there were 
no differences in morphology between the control groups and the treatment groups. However, most fish had not fully completed the transformation to juveniles, and subsequent experiments need to be conducted for longer time periods and the fish evaluated until most control individuals have fully completed metamorphosis to juveniles. These additional studies will be done in FY 2011.

\subsubsection{California Halibut}

California halibut were also used as a model organism to evaluate the effect of EMF exposure on fish development. California halibut were received from The Cultured Abalone, Ltd. (Santa Barbara, California) at the Marine Sciences Laboratory within $72 \mathrm{hr}$ of hatching. Through preliminary culturing efforts, we developed a protocol that maximized fish survivability and permitted testing during the critical period when metamorphosis is occurring. Using this new protocol, larval California halibut were cultured until approximately 32 days post-hatch (or approximately 1 week before the start of eye migration). Larval staging was examined prior to the start of exposure, and larvae were distributed across treatment groups based on size and developmental stage; each group received equal numbers of each stage.

California halibut were contained in 2.5-gal aquaria nested in large water baths (Figure 2.3.). Each aquarium contained 18-20 fish, with two replicates of control non-exposed tanks and two replicates of EMF-exposed tanks. Fish were held in their respective treatment tanks until all fish in the control nontreated tank underwent eye migration. After the experiment ended, each fish was measured for standard length, eye migration stage, pigmentation pattern, and developmental stage. As with the Atlantic halibut data, there were no noticeable differences between control non-exposed fish and fish exposed to $3 \mathrm{mT}$ EMF. Additional studies planned for FT 2011 will repeat this experiment using a larger number of individuals to confirm the lack of response towards a $3 \mathrm{mT}$ EMF exposure.

\subsection{FY11 Activities}

During the first half of FY11, follow-on testing of the Coho and halibut fish species will be conducted using larger sample sizes to allow rigorous statistical evaluation of the experimental results. The halibut studies will monitor individuals until the majority of control fish have completed metamorphosis to juveniles. This will permit assessment of any time delays in metamorphosis as a result of EMF exposure.

During the second half of FY11, PNNL staff will initiate further testing based on the evaluation of the initial test results from above. This may include testing of other commercially, recreationally, or environmentally relevant species using the current Helmholtz coil configuration, and/or utilizing the Helmholtz coil in a different configuration that permits assessment of changes in movement behavior (attraction or avoidance) in the presence of non-uniform EMF. Staff will also consider the use of candidate elasmobranch species (sharks, skates), given the evidence that these species may be attracted to power cables and other electrical structures. Because sharks and skates are generally not available from commercial suppliers, it may be necessary to procure wild-caught organisms to support future laboratory testing. 



\subsection{Invertebrate Experiments}

\subsection{Dungeness Crab Behavioral Experiments}

For the initial invertebrate trials, a decapod crustacean, the Dungeness crab (Cancer magister), was chosen as a representative bottom-dwelling species for test exposures to EMF. Dungeness crab are considered an important recreational and commercial fishery specie on the West Coast, ranging from the Gulf of Alaska to California. They are opportunistic predators, foraging on available bivalves, crustaceans, and fish. Various life stages of this species live in intertidal estuarine habitats to deeper waters offshore and are thus representative of an organism that could by impacted by EMF exposures from underwater cables.

The initial experiments with Dungeness crab were designed to determine whether an EMF field strength of $3.0 \mathrm{mT}$ could be detected by the crabs using one of their chemosensory receptors, the antennule (Figure 3.1). The basic premise is that measurement of the antennular flicking rate is a quantitative measure of chemosensory acuity in the water column. This has been demonstrated with blue crab (Callinectes sapidus) for food extracts (Pearson and Olla 1977) and naphthalene (Pearson and Olla 1979) and with Dungeness crab for food extracts (Pearson et al. 1979), petroleum hydrocarbons (Pearson et al.1981), and salinity (Sugarman et al. 1983). Although the antennule has been shown to be involved in recognition of primarily chemical cues in the water, it is not known to what extent the antennules might detect an electromagnetic field generated in the water column. Initial experiments were designed to measure the antennular flicking rate pre- and post-exposure to EMF in a controlled laboratory setting.

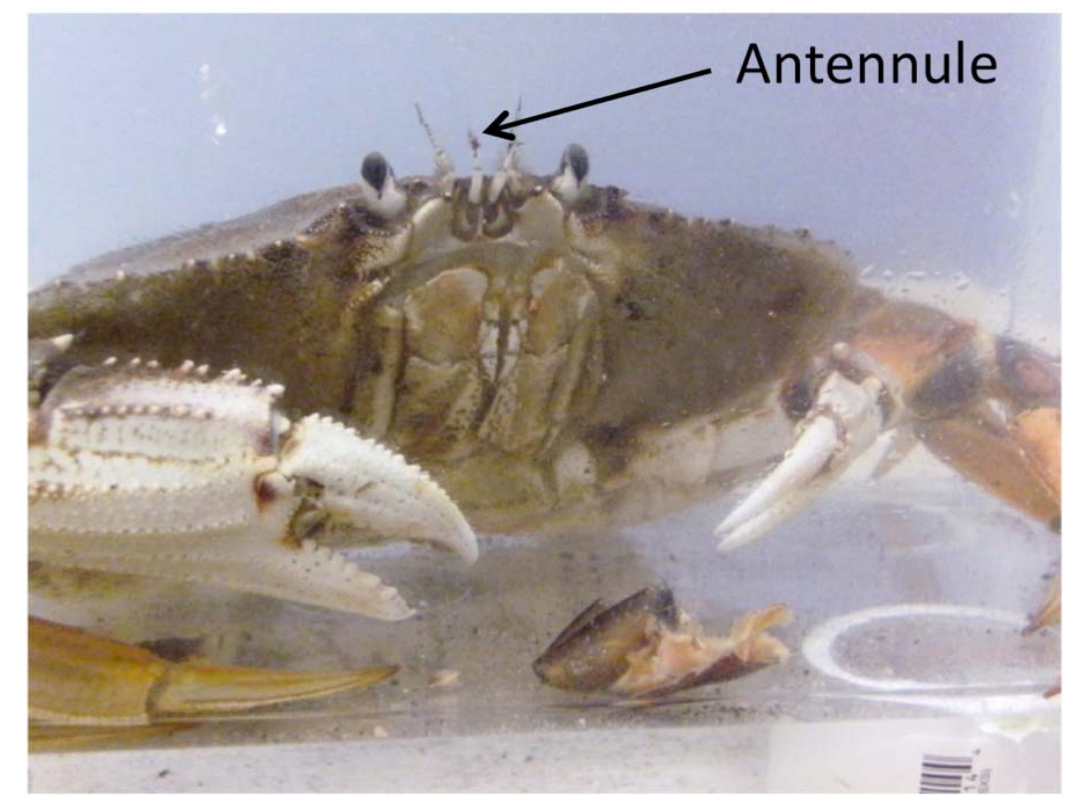

Figure 3.1. Antennules of Dungeness Crab Used in the EMF Exposure Tests

For the initial exposure trials, adult male Dungeness crab were collected from the Strait of Juan de Fuca and held at the Marine Sciences Laboratory in outdoor tanks with a 20-cm layer of sand and flowthrough unfiltered seawater from Sequim Bay. Crabs were provided an ad libitum diet of native bivalves until testing was conducted. 
At the time of this reporting, initial exposure trials were just getting under way. Hence, the methods described here may be adjusted slightly, once the training trials are complete. For each exposure test, four tanks containing an individual crab will be placed in the EMF-generated test space (Helmholtz coil description, Section 2) with the power turned off. Each exposure tank (11.75 in. long $\times 7.75 \mathrm{in}$. wide $\times 8$ in. high) is equipped with an opaque Plexiglas cover clamped to it. A funnel and acrylic inlet manifold deliver about $1.5 \mathrm{~L} / \mathrm{min}$ of $35-\mu \mathrm{m}$ filtered seawater from a dripper and manifold to the bottom of each chamber (Figure 3.2). Daylight spectrum lighting (approximately 500 lux) will be provided on a photoperiod synchronized to civil sunrise and sunset. Crabs will be transferred from the outdoor holding tanks to the test chambers $24 \mathrm{hr}$ before testing to allow for acclimation.

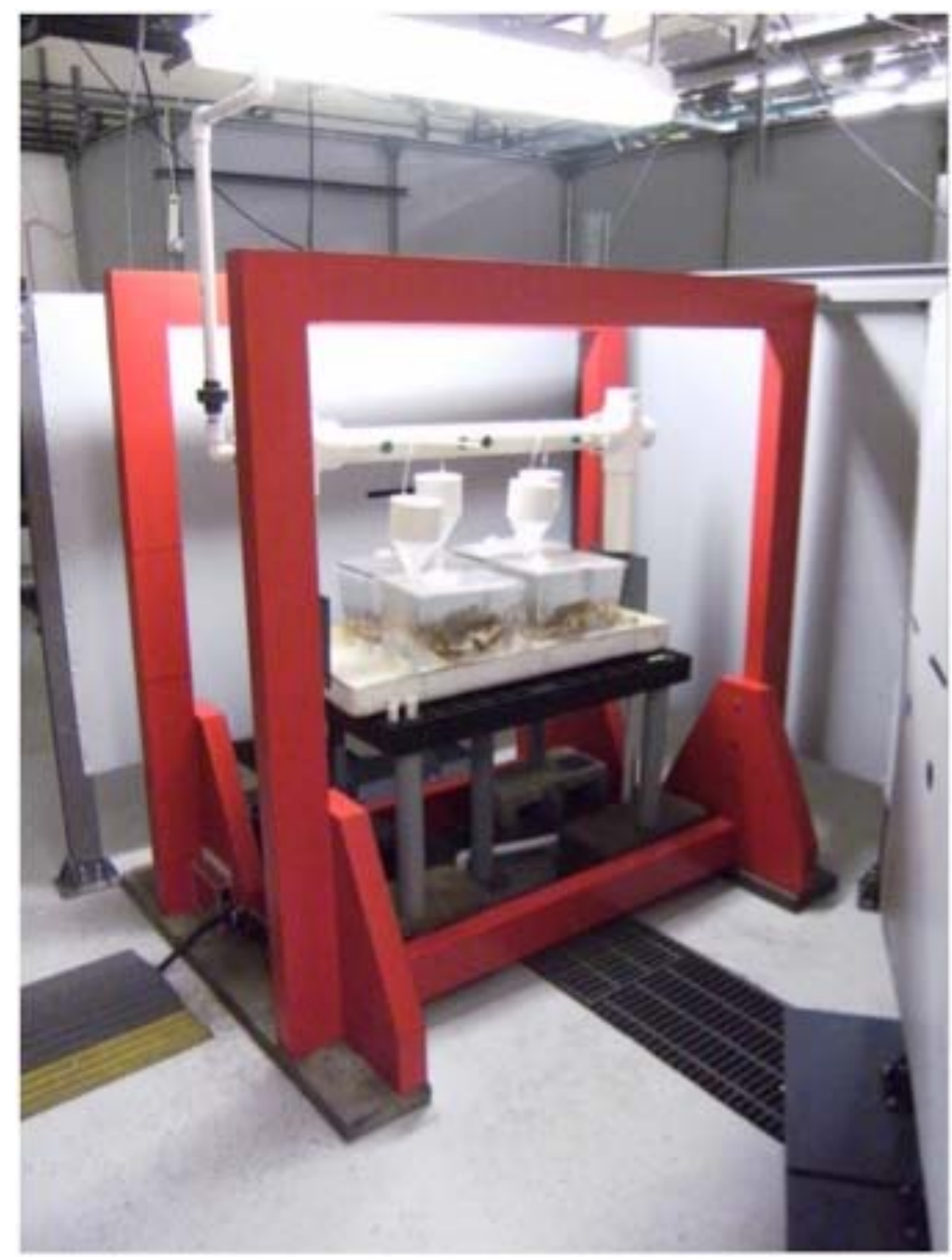

Figure 3.2. Exposure System for Dungeness Crab 
During each day of testing, partitions will be placed around the testing apparatus to reduce visual disturbance to the crab prior to and during testing. Small openings in the partition will allow for video recording of the data and collection of observer data (Figure 3.3). For each test, individual crab will be observed and digitally recorded by trained observers. The antennular flicking rate and other behaviors will be recorded for $1 \mathrm{~min}$. The Helmholtz coil will then be turned on, delivering a 3-mT EMF exposure dose, and the flicking rate and behaviors recorded for at least 1 min thereafter. Other behaviors, such as a change in antennnular orientation, beating of maxillipedal flagella, dactyl searching, and chelae probing, also will be recorded. Approximately $30 \mathrm{crab}$ will be tested in this manner. The data will be then analyzed statistically to determine if there is a difference in antennular flicking rates and other behaviors noted before the EMF exposure compared to after EMF exposure.

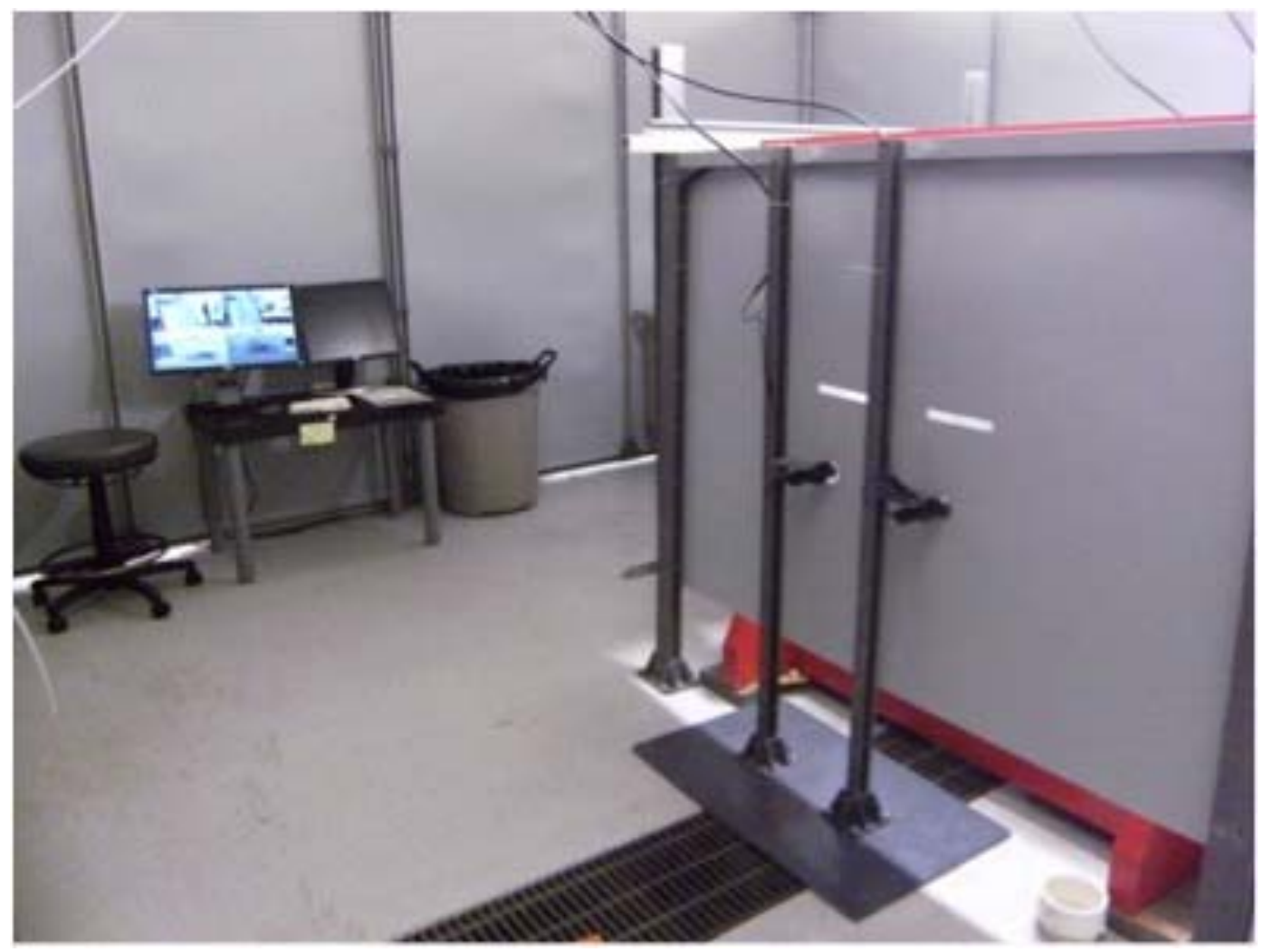

Figure 3.3. Visual Partitions, Recording Cameras, and Monitoring System for Dungeness Crab Studies

\subsection{FY11 Activities}

During the first part of FY11, the antennular flicking experiments will be completed with Dungeness Crab, including the initial detection response and a comparative response in the ability to detect an odor stimulant before and after exposure to EMF. During the second part of FY11, experimentation will focus on laboratory mesocosm exposures to assess avoidance/attraction behaviors and the ability to locate prey using Dungeness crab. Staff will also consider experiments to examine the differences in antennular flicking response in other relevant crustaceans including blue crab and lobster (e.g. American, Spiny). 



\subsection{References}

Brown GE and RJF Smith. 1997. Conspecific skin extracts elicit antipredator responses in juvenile rainbow trout (Oncorhynchus mykiss). Canadian Journal of Zoology 75(11):1916-1922.

Gisbert E, G Merino, JB Muguet, D Bush, RH Piedrahita, and DE Conklin. 2002. Morphological development and allometric growth patterns in hatchery-reared California halibut larvae. Journal of Fish Biology 61:1217-1229.

Pearson WH and BL Olla. 1977. Chemoreception in the blue crab, Callinectes sapidus. The Biological Bulletin 153:346-354.

Pearson WH and BL Olla. 1979. Detection of naphthalene by the blue crab, Callinectes sapidus. Estuaries 2(1):64-65.

Pearson WH, PC Sugarman, and DL Woodruff. 1979. Thresholds for detection and feeding behavior in the Dungeness crab Cancer magister (Dana). Journal of Experimental Marine Biology and Ecology 39:65-78.

Pearson WH, PC Sugarman, DL Woodruff, and BL Olla. 1981. Impairment of the chemosensory antennular flicking response in the Dungeness crab, Cancer magister, by petroleum hydrocarbons. Fishery Bulletin 79(4):641-647.

Sæle Ø, JS Solbakken, K Watanabe, K Hamre, D Power, and K Pittman. 2004. Staging of Atlantic halibut (Hippoglossus hippoglossus L.) from first feeding through metamorphosis, including cranial ossification independent of eye migration. Aquaculture 23:445-465.

Scholz NL, NK Truelove, BL French, BA Berejikian, TP Quinn, E Casillas, and TK Collier. 2000. Diazinon disrupts antipredator and homing behaviors in Chinook salmon (Oncorhynchus tshawytscha). Canadian Journal of Fisheries and Aquatic Sciences 57(9):1911-1918.

Sugarman PC, WH Pearson, and DL Woodruff. 1983. Salinity detection and associated behavior in the Dungeness crab, Cancer magister. Estuaries 6(4):380-386.

Stone SL and CB Schreck. 1994. Behavioral responses of juvenile coho salmon (Oncorhynchus kisutch) to pulp mill effluents. Bulletin of Environmental Contamination and Toxicology 52(3):355-359.

Tierney KB, AL Taylor, PS Ross, and CJ Kennedy. 2006. The alarm reaction of coho salmon parr is impaired by the carbamate fungicide IPBC. Aquatic Toxicology 79(2):149-157. 


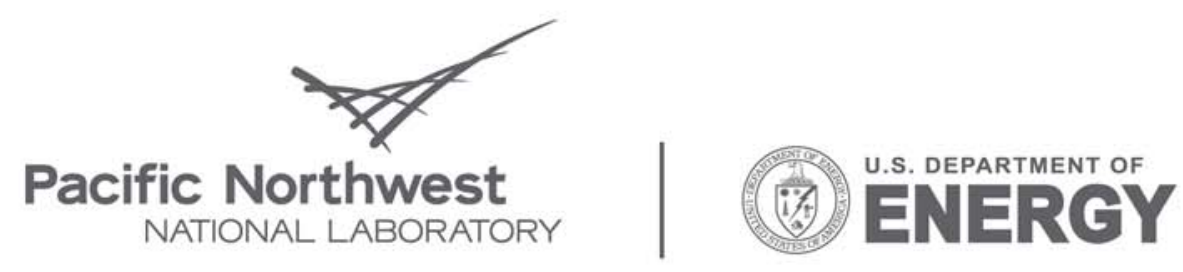

Proudly Operated by Battelle Since 1965

902 Battelle Boulevard

P.O. Box 999

Richland, WA 99352

1-888-375-PNNL (7665)

www.pnl.gov 